\title{
PENGARUH GAME ONLINE PUBG (Player Unknown's Battle Ground) TERHADAP PRESTASI BELAJAR PESERTA DIDIK
}

\author{
Ach Fauzi ${ }^{1}$ \\ ${ }^{1}$ Mahasiswa Program Studi Pendidikan IPA, Pendidikan MIPA \\ Fakultas Keguruan dan Ilmu Pendidika, Universitas Jember \\ email: ach.fauzi7@yahoo.com
}

\begin{abstract}
ABSTRAK
Salah satu permainan berbasis online yang sedang populer sekarang adalah PUBG. Permainan berbasis online ini baik digunakan sebagai alternatif rekreasi pelajar namun harus disertai kontrol diri karena jika pemain sudah mulai kecanduan akan berakibat prestasi akademik menurun. Penelitian ini menggunakan pendekatan kualitatif deskriptif dengan teknik pengumpulan data berupa metode observasi, metode wawancara. Tujuan dari penelitian ini yaitu menjelaskan bagaimana pengaruh game online PUBG pada prestasi akademik Siswa. Hasil penelitian dapat disimpulkan bahwa pengaruh game online PUBG terhadap prestasi belajar siswa menyatakan bahwa salah satu permainan berbasis online ini sangat digemari karena mendapat kesenangan, mengurangi stress, bertemu dan berkenalan dengan banyak teman, gratis, meningkatkan kerjasama, meningkatkan kempampuan berbahasa inggris, terhindar dari pergaulan bebas dan narkoba, dan permainan yang dapat dimainkan dimana dan kapan saja, namun setiap permainan jika tidak diimbangi dengan kontrol diri maka akan membuat pemainnya kecanduan dan membuat prestasi belajar siswa menurun.
\end{abstract}

Kata Kunci : Game Online; PUBG; Prestasi Belajar

ABSTRACT

One of the popular online games now is PUBG. This online-based game is an alternative to learners but should apply when players are getting addicted will result in decreased academic achievement. This research uses descriptive technique with data collection technique, technique, interview method. The purpose of this study is to explain the game online PUBG on student academic. The result of the research can be concluded that the influence of game online PUBG on student learning achievement of online game is very popular because got satisfaction, reduce stress, meet and get acquainted with many friends, free, increase cooperation, speak english, avoid free association and drugs, and games that can be used anywhere and anytime, but any game if not balanced with self-control will make players addicted and make student achievement decreased.

Keywords: Online Game; PUBG; Learning Achievement.

\section{PENDAHULUAN}

Semakin populernya game online mengakibatkan gamers (pemain game) menjadi ketagihan akan game tersebut. Fase ketagihan dalam memainkan games ialah situasi dimana seseorang gamers sangat susah dalam melepaskan dirinya dari gamenya tersebut. Ketagihan game mampu menyebabkan kerugian yang tinggi. Contohnya yaitu gamers bisa menjadi gagal akan kehidupan real-nya dikarenakan sudah sangat terjerumus didalam game tersebut. Gamers biasanya merelakan waktu dari hobinya, merelakan jangka waktu tidurnya, merelakan pekerjaannya maupun waktu belajarnya, dan merelakan waktunya dengan keluarga. Game online juga bisa menyebabkan pola makan serta pola tidur terganggu, serta kesehatan akan terganggu. Merebaknya kepopuleran game online PUBG diduga menjadi salah satu faktor yang memotivasi gamers untuk ketagihan.

Gejala ketagihan game online diduga akan mempengaruhi prestasi akademik mahasiswa. Kebutuhan berprestasi adalah salah satu dari sekian kebutuhan dasar manusia berdasarkan teori keperawatan yang dikemukakan oleh Jean Watson. Kebutuhan prestasi merupakan kebutuhan psikososial atau kebutuhan integrasi yang dimiliki oleh setiap individu. Prestasi akademik tergantung dari sejauh mana faktor-faktor penunjang mempengaruhi pelajar. Semakin baik atau meningkatnya 
faktor penunjang tersebut maka semakin baik juga prestasi akademik yang diperoleh (Theresia, 2012).

Bermain ialah aktivitas yang dilakukan demi keinginan individual, dilakukan dengan metode yang menggembirakan, tidak ditujukan pada hasil final, aktif, fleksibel serta aktual. Artinya, bermain bukanlah aktifitas yang dikerjakan untuk mempuaskan orang lain,tapi hanya karena keinginan dari dirinya sendiri. Bermain juga merupakan kegiatan menyenangkan yang sifatnya pribadi dan fleksibel. Umumnya bermain menimbulkan efek positif karena bermain merupakan bagian proses bagi pertumbuhan siswa. Kegiatan tersebut dilakukan dengan suka rela, tanpa adanya pemaksaan ataupun tekanan dari pihak luar.

Peserta didik merupakan orang yang belum dewasadan memiliki sejumlah potensi dasar (fitrah) yang perlu dikembangkan. Peserta didik merupakan "Raw Material" (Bahan Mentah) dalam prosestransformasi dan implementasi, menepati posisiyang sangat penting untuk melihat signifikasinya dalam menemukan keberhasilan sebuah proses. Peserta didik adalah makhluk individu yang mempunyai kepribadian dengan ciri-ciri yang khas yang sesuai dengan pertumbuhan dan perkembangannya. Pertembuhan dan perkembangannya dipengaruhi oleh lingkungan dimana ia berada. Peserta didik adalah anggoata masyarakat yang berusaha mengembangkan potensi diri melalui proses pembelajaran yang tersedia pada jalur, jenjang dan jenis pendidikan tertentu. Siswa adalah komponen yang tidak bisa dipisahkan dari sutu sistem pendidikan sehingga dapat dikatakan bahwa peserta didik merupakan obyek pendidikan tersebut (Ramli, 2015).

Permainan berbasis online (Game Online) adalah suatu permainan yang dapat dimainkan oleh banyak pemain dengan menggunakan media mesin dimana mediamedia tersebut harus terhubung pada suatu jaringan, biasanya jaringan yang sering dipakai disebut internet (Affandi, 2013).

Permainan berbasis online ini sudah tersebar dan banyak dikenal masyarakat terutama dikalangan pelajar. Banyak orang yang mengira bahwa permainan online hanya dapat dimainkan dengan komputer, tetapi nyatanya permainan ini tidak hanya dapat dimainkan dengan komputer. Permainan berbasis online bisa dimainkan dengan konsol, handled, dan telepon genggam. Permainan berbasis online baik dimanfaatkan sebagai alternatif pemain untuk refreshing. Permainan ini juga ampuh untuk menghilangkan rasa jenuh karena kegiatan sehari-hari yang cukup membosankan seperti belajar, bekerja, dan lain-lain. Terkadang pemain bermain permainan ini sekadar mengisi waktu luang.

Menurut sejarah perkembangan permainan berbasis online, perkembangan permainan ini erat kaitannya dengan perkembangan teknologi komputer dan jaringan kompoter. Kepopuleran permainan berbasis online ini dikarenakan pesatnya jaringan komputer yang pada jaman dulu hanya lingkup kecil (Small Local Network) hingga sekarang menjadi internet dan mengalami terus perkembangan. Permainan berbasis online yang sangat terkenal di masa sekarang tidaklah sama dengan permainan berbasis online saat baru diperkenalkan pertama kalinya. Pada tahun 1960, komputer yang saat itu baru dikenalkan hanya dapat digunakan oleh 2 orang untuk bermain game. Kemudian muncullah komputer yang dapat digunakan oleh banyak orang untuk bermain game dan dapat bermain secara bersamaan di tempat yang berbeda (Akramina, 2016).

PUBG (PlayerUnknown's BattleGround) adalah sebuah game multiplayer kompetitif yang menjadikan "Battle-Royale" sebagai genre utama. Battle-Royal sendiri merupakan sebuah filem klasik jepang populer pada tahun 2000 silam, yang diadaptasikan dari sebuiah novel keluaran tahun 1999.

PUBG memuat pertempuran 100 orang secara bersamaan di sebuah area yang besar, yang semuanya datang tanpa perbekalan apapun. Setiap dari mereka harus memperkuat dan mempersenjatai diri mereka dengan apapun yang mereka temukan di arena yang ada, dari sekedar panci penggorengan untuk senjata melee, boody armor untuk menahan sedikit laju 
peluru, hingga senjata api kaliber berat. Bisa juga menemukan kendaraan air atau darat untuk ekstra mobilitas. Ini perlu bertahan hingga akhir, dan menjadi satu-satunya player yang selamat ditengah pertempuran. Tidak banyak kesempatan bersembunyi hanya satu tempat saja, karena daerah dimana player bisa bergerak akan terus diperkecil seiring dengan waktu berjalan di sebuah arena besar yang terus memaksa pemain untuk berhadapan langsung dengan satu sama lain. Selain bermain solo, juga bisa bermain dalam format Duo (2 orang) dan juga squad (4 orang), baik secara acak atau dengan mengundang teman dari Friend List. Bermain dalam format kooperatif seperti ini lebih sulit karena lawan akan bergerak dalam format strategi tertentu, maka perlu memikirkan lebih banyak strategi untuk kemenangan (Santoso, 2017).

Arifin tahun 1990 menyatakan bahwa prestasi belajar berawal dari bahasa Belanda, dimana prestasi dapat diartikan sebagai hasil upaya. Prestasi belajar ialah hasil aktivitas yang suddah dibuat atau didapatkan dengan cara kerajinan berkerja. Berlandaskan definisi diatas, dapat dikatakan bahwa prestasi belajar ialah hasil yang sudah diraih atau hasil yang sudah didapatkan subjek belajar atas kegigihan dan kesungguhan dalam bekerja. Latar pendidikan lama semacam yang sedang dipakai kurikulum pendidikan di Indonesia, beberapa tolak ukur yang digunakan sebagai penilai berhasilnya metode belajar itu ialah prestasi akademik siswa . Prestasi atau kemampuan (kinerja) ialah hasil puncak dari sebuah kegiatan, disisi lain prestasi belajar yang didapatkan mahasiswa sesudah kegiatan belajar mengajar berjalan, jadi diadakan evaluasi. Kompetensi pengetahuan atau keterampilan yang dikmbangkan oleh mata pelajaran normalnya diperlihatkan dengan hasil test atau indeks prestasi yang diberikan oleh guru.

Didalam lingkungan pendidikan, mengevaluasi termasuk salah satu kegiatan yang tidak bisa diabaikan. Mengevaluasi ialah salah satu kegiatan dalam mengajar dan belajar. $\mathrm{Di}$ Indonesia, proses mengevaluasi prestasi belajar lingkungan akademik di sekolahsekolah dituang kedalam suatu buku laporan yang disebut rapot. Dalam buku laporan itu dapat didapati seberapa tinggi prestasi belajar mahasiswa, apa mahasiswa itu gagal ataukah berhasil didalam subyek pelajaran tertentu.

Performance (prestasi) ialah hasil yang diinginkan dari kepribadian atau perilaku. Perilaku yang berkaitan dengan prestasi ialah perilaku yang berhubungan langsung dengan kewajiban pekerjaan serta yang harus dirampungkan demi mencapai suatu target pekerjaan. Prestasi akademik merupakan pertunjukan dari pengetahuan atau skill sehabis didapat. Bahwasannya nilai prestasi mesti menggambarkan jenjangjenjang siswa, seberapa jauh siswa telah menggapai sasaran yang ditetapkan disetiap mata pelajaran (Poerwati, 1945).

\section{METODE PENELITIAN}

Penelitian ini dilakukan dengan mengunakan pendekatan kualitatif. Pendekatan kualitatif ialah penelitian yang sumber informasinya berbentuk gambar, kata serta bukan berbentuk numerik yang didapat dari hasil tanya jawab, dokumendokumen dan lain sebagainya, atau penelitian yang didalamnya mementingkan dalam menggambarkan secara analisis sebuah fenomena atau proses sebagaimana tersedia lingkungan yang alami demi mendapatkan hakikat yang mengakar dari proses tersebut. Metodologi kualitatif sebagai metode pengkajian dimana diperoleh fakta deskripsi yang berupa perkataan tertulis atau lisan dari informan dan perilaku yang diteliti (Lexy, 2004:4).

Model penelitian yang digunakan peneliti ialah model dskriptif kualitatif. Dimana model ini mendalami permasalahan yang timbul dan aturan kerja yang berlaku, Penelitian deskriptif kualitatif ini memiliki tujuan agar dapat mendeskripsikan hal-hal atau apa-apa yang saat ini sedang berlaku.

Sumber data yang diperoleh yaitu sumber data primer dan sekunder. Seperti diketahui bahwa data primer adalah data yang secara langsung dikumpulkan dan diperoleh dari wawancara yang didalamnya bersangkutan dengan apa yang terdapat pada observasi dan pedoman wawancara. 
Data sekunder yakni data yang dikumpulkan, diolah dan disajikan oleh pihak lain dalam bentuk publikasi atau jurnal, Penggunaan buku, jurnal, dan dokumen peneliti pilih dan gunakan sebagai data sekunder. Diharapkan dengan adanya sumber data tersebut dapat memberikan deskripsi terhadap fenomena permainan game PUBG pada prestasi akademik peserta didik.

Teknik pengumpulan data yang dilakukan peneliti yaitu melalui wawancara, dimana peneliti menyiapkan pertanyaan sebelumnya untuk digunakan sebagai bahan wawancara secara langsung. Hal ini dilakukan bertujuan untuk memperoleh data secara lebih luas dan menyeluruh sesuai dengan kondisi yang terjadi di lapang. Teknik yang kedua adalah observasi langsung. Observasi langsung yang direalisasikan dengan cara mencatat informasi-informasi yang berhubungan dengan pemain game PUBG nilai siswa yang bermain game ini.

\section{HASIL DAN PEMBAHASAN}

Penelitian ini mengambil subyek yaitu peserta didik dalam permainan game online PUBG. Subyek dilihat melalui standar yang seirama dengan penelitian ini. Analisa deksriptif dari hasil penelitian ialah analisa terhadap informasi yang di dapat melalui proses tanya-jawab, dimana narasumber tersebut adalah pemain aktif Game online PUBG. Melalui proses tanya-jawab bersama para responden, maka menganalisa pengaruh game online PUBG terhadap prestasi belajar peserta didik.

Berikut adalah data dasar yang menerangkan informasi narasumber :

Tabel 1. Informasi Narasumber

\begin{tabular}{llll}
\hline No & Nama & Kelas & Sekolah \\
\hline 1. & Andre Maulana & IX & SMP Negeri 2 Pegantenan \\
\hline 2. & M Iqbal Putra & IX & SMP Negeri 2 Pegantenan \\
\hline 3. & Ardi Saputra & IX & SMP Negeri 2 Pegantenan \\
\hline 4. & Akhbar Rikzan K P & IX & SMP Negeri 2 Pegantenan \\
\hline 5. & Fariz Bagas & X & SMK Al-Karomah \\
\hline 6. & Faris Sulaiman & X & SMK Al-Karomah \\
\hline 7. & Gibson Ireneus I N & X & SMK Al-Karomah \\
\hline 8. & Royhan Firdausi & XI & SMK Al-Karomah \\
\hline 9. & Irham Wahyudi & XI & SMK Al-Karomah \\
\hline 10. & M Harris Amirullah & XI & SMK Al-Karomah \\
\hline 11. & Yusuf Maulana & XII & SMK Al-Karomah \\
\hline
\end{tabular}

Analisa deskriptif dari hasil penelitian ialah analisa terhadap informasi yang di dapat melalui proses tanya-jawab bersama 12 orang narasumber, dimana narasumber tersebut adalah pemain aktif Game online PUBG. Melalui proses tanya-jawab bersama para responden, maka peneliti mampu menganalisa akan pengaruh game online PUBG terhadap prestasi belajar.

Dari 12 narasumber yang telah diwawancara, 6 orang dari semua 
narasumber mengetahui game inidalam waktu yang lama. 6 narasumber ituyaitu $M$ Iqbal Putra, Ardi Saputra, Akhbar Rizkan, Fariz Bagas, Faris Sulaiman, dan M Fadil Rifani yangsudah 2 tahunan memainkan Game online PUBG, sedangkan sisanya bermain game ini dalam kurun waktu kurang dari 1 tahun.

Hal ini menunjukkan bahwa fenomena Permainan Game online PUBG menyebar dikarenakan terjadinya kecenderungan yang muncul didalam lingkungan siswa tersebut. Demi tercapainya kepentingan sosial terhadap suatu gaya hidup serta pengakuan diri, jadi dipaksa atau siswa yang msuk didalam pergaulan itu pasti meniru mode itu. Pada topik ketagihan 9 narasumber memberi pengakuan yaitu ketagihan serta 3 orang mengaku tidak terlalu kecanduan.

Sedang dari pada itu dalam topik seringnya para saat memainkan Game online PUBG. Menurut pengakuan narasumber, mereka setidaknya menghabiskan 1-6 jam/hari demi memainkan Game online Mobile Legends. Dari 12 narasumber yang diteliti, 4 orang menghabiskan rata-rata 1 jam, 5 orang bermain 3 jam perhari, sedangkan 3 orang bermain selama 6 jam/hari emi memainkan Game online PUBG. Selain dampak negatifnya yang mendorong para gamers untuk memainkan Game online PUBG menjadi ketagihan, juga terdapat benefit yang bisa diambil dari permainan Game online PUBG ini.

Game online adalah game yang terbaru yang mulai muncul di Indonesia tahun 2001. Seiring bertambahnya tahun pembaharuan game online ini semakin maju mulai dari fitur-fitur terbaru dan yang jumlah pemainya sangat beragam pula. Di era sekarang koneksi internet sangat mudah yang membuat semakin maraknya pengguna game online di Indonesia terutama di kotakota.

Pengguna game online ini tidak hanya di kalangan remaja namun anak yang masih duduk di sekolah dasar sudah mengenal game online akibat mudahnya informasi yang di peroleh dari internet. Meskipun terdapat dampak positif dari game online itu sendir, tanpa sadari game online ini banyak memberikan pengaruh negative bagi para pemainnya. Dari hasil wawancara dengan banyak narasumber mereka berasumsi bahwa game online hanyalah sebuah hiburan yang mereka gunakan untuk mengisi waktu luang.

Bentuk non material (sesuatu yang dapat di tangkap nyata) dari fenomena permainan Game online PUBG adalah:

1. Menimbulkan adiksi (Kecanduan) yang kuat

Game online PUBG merupakan game online yang memiliki kepopuleran pada saat ini, game strategi yang memiliki cara permainan yang sedeerhana yakni hanya membunuh lawan dan menjaga diri sendiri agar dapat memenangkan permainan.

2. Terbengkalainya kegiatan di dunia nyata

Game online adalah sarana bermain yang menarik yang dapat dilakukan dengan penuh keseruan asal para pemainnyadapat membagi waktu dengan baik.

3. Pemborosan

Meskipun dikatakan permainan Game online PUBG gratis namun game online memerlukan sambungan internet yang dapat diakses melalui paket data dari provider jasa internet atau jaringan nirkabel berbasis WIFI, berdasarkan wawancara mereka ratarata menghabiskan uang untuk membeli paket dengan kisaran Rp 20.000 - Rp 50.000 per minggu, jika dihitung dalam sebulan sudah dapat ratusan ribu uang yang dihabiskan hanya untuk mengisi waktu luang dan bersenang-senang atau berkumpul dengan sesama komunitas.

\section{KESIMPULAN}

Permainan Game online PUBG merupakan permainan yang membuat para pemain merasa ambisius dalam artian jika bermain kalah akan mempunyai niat lagi untuk bermain sampai menang, dan jika menang ingin main lagi, dan terus ingin membuat peserta didik mengalami kecanduan, jika tidak bisa membagi waktu antara bermain game online dengan tugas dan kewajiban sebagai siswa. Apabila peserta didik menjadi pecandu Game online PUBG bisa menjadi nilai prestasi akademik di sekolah menurun sehingga belajar 
berrmalas-malasan mengerjakan tugastugas, jika peristiwa ini terus berlanjut tanpa disadari maka peserta didik tersebut terancam dikeluarkan dari sekolah dengan nilai yang terlalu rendah. Tetapi ada pula pemain Game online PUBG yang bisa membagi waktu antara bermain dan tugas sebagai siswa, semua kembali pada individu masing- masing dalam menyikapi fenomena sosial tersebut.

\section{SARAN DAN UCAPAN TERIMA KASIH}

Setiap siswa pasti mengharapkan memperoleh prestasi akademik yang baik sehingga membanggakan kedua orang tua yang telah membiayai agar pserta didik dapat menggapai impian dari tujuan awal mereka sekolah, tetapi peserta didik banyak yang tidak sadar, mereka sudah dianggap dewasa jadi bisa membedakan sendiri antara yang baik dan tidak baik bagi dirinya.

Dalam penyusunan artikel ini tidak terlepas dari dukungan berbagai pihak. Penulis secara khusus mengucapkan terimakasih yang sebesar-besarnya kepadsa semua pihak yang telah membantu. Penulis banyak menerima petunjuk dan bantuan serta dorongan dari berbagai pihak baik yang bersifat moral maupum material. Pada kesempatan kali ini penulis menyampaikan terimaksih yang sebesar-besarnya kepada Allah SWT dengan segala rahmat dan karunia-Nya yang memberikan kekuatan bagi penulis dalam menyelesaikan artikel ini. Kepada orang tua yang selama ini telah membantu penulis dalam bentuk perhatian, kasih sayang, semangat, serta doa yang tidak henti-hentinya mengalir demi kelancaran dan kesuksesan penulis dalam menyelesaikan artrikel ini. Segenap guru dan staf SMP Negeri 2 Pegantenan dan SMK Al-Karomah yang telah membantu dalam memberikan fasilitas, ilmu, serta pendidikan pada penulis sehingga dapat menunjang dalam menyelesaikan artikel ini serta masih banyak lagi pihak-pihak yang sangat berpengaruh dalam proses penyelesaian artikel yang tidak bisa penulis sebutkan satupersatu.

\section{DAFTAR PUSTAKA}

Affandi, M. 2013. Pengaruh Game Online Terhadap Tingkat Efektifitas Komonikasi Interpersonal pada Kalangan Pelajar Kelas 5 SDN 009 SAMARINDA, I(4), 177-187.

Akramina, Y. 2016. Pengaruh Bermain Game Online Terhadap Efektifitas Swarga Bara Kota Sangatta, 4(1), 189-199.

Jeanete, O.P. 2016. Identifikasi Gaya Belajar Mahasiswa, n, 15(1), 56-63.

Lexy, M. 2004. Metode Penelitian Kualitatif. Bandung : Remaja Rosdakarya.

M.Ramli. 2015. Hakikat Pendidikan dan Peserta Didik. Tarbiyah Islamiyah. 5(1)

Poerwati, T. 1945. Akuntansi di UNIVERSITAS STIKUBANK ( UNISBANK) Semarang.

Santoso, Pladidus. 2017. Review Playerknown's

Battlegrounds(PUBG): Populartas Sepadan!. (On-line) melalui $<$ http://jagatplay.com/2017/12/pc-

2/review-playerunknownsbattlegrounds-pubg-popularitassepadan/3/

Tedjasaputra, Mayke S. 2001. Bermain, Mainan, dan Permainan. Jakarta : Gramedia Widiasarana Indonesia.

Theresia, L. G. 2012. Hubungan Kecanduan Game Online Dengan Prestasi Akademik Mahasiswa Di 